\title{
Knowledge, attitude and practices of the university students about COVID-19 during the Luzon lockdown in the Philippines
}

\author{
Jomell M. Santiago ${ }^{1}$, Angelo R. Santos ${ }^{2}$ \\ ${ }^{1}$ College of Education, Nueva Ecija University of Science and Technology San Isidro Campus, Philippines \\ ${ }^{2}$ College of Management and Business Technology, Nueva Ecija University of Science and Technology San Isidro \\ Campus, Philippines
}

\begin{tabular}{l} 
Article Info \\
\hline Article history: \\
Received Jan 19, 2021 \\
Revised Jun 6, 2021 \\
Accepted Jun 23, 2021 \\
\hline
\end{tabular}

\section{Keywords:}

Attitude

Campaign

COVID-19

Knowledge

Lockdown

Practices

\begin{abstract}
The Philippines is one of the many countries around the world that imposed lockdowns to stop the transmission of coronavirus disease 2019 (COVID19). During the lockdown period, the Department of Health carried out a massive information dissemination campaign about COVID-19. Thus, the researchers want to determine the knowledge, attitude and practices of the students about the COVID-19 during the Luzon lockdown. A descriptive research design and purposive sampling were used. A questionnaire was utilized to collect data composed of the profile, questions regarding their knowledge, attitude and practice towards COVID-19 and their source of knowledge. Permission to conduct and informed consent was obtained. Data were analyzed using various statistical tools. The majority of the respondents had well to very good knowledge of COVID-19 and their source of knowledge was mainly from television and the internet. They also had a very positive attitude and they practice the different ways to prevent COVID-19. The difference between their gender and family income to their knowledge about COVID-19 was significant. Therefore, an intensified campaign should be done to reach those individuals who have limited access to television and the internet and help them to have a positive attitude and correct practices towards COVID-19.
\end{abstract}

This is an open access article under the CC BY-SA license.

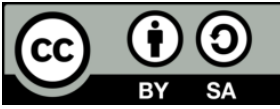

\section{Corresponding Author:}

Jomell M. Santiago

College of Education

Nueva Ecija University of Science and Technology San Isidro Campus

3106 Poblacion, San Isidro, Nueva Ecija, Philippines

Email: jomellsantiago8854@gmail.com

\section{INTRODUCTION}

In December of this year, a coronavirus 2 outbreak of extreme acute respiratory syndrome occurred, previously known as 2019-nCoV, occurred in the Chinese city of Wuhan, in the province of Hubei, and spread across China and beyond [1], [2] stated that COVID-19 did not belong to the previous coronaviruses group associated with humans such as severe acute respiratory syndrome (SARS) and middle East respiratory syndrome (MERS) through genomic sequencing and evolutionary differentiation analysis. This novel coronavirus strain, known as SARS-CoV-2, is thought to have originated in bats before being transmitted to humans by another species, such as a pangolin (scaly anteater). In the so-called "wet market," where several wild animal species are close to each other for selling purposes, it was believed where people most likely came into contact [3].

To further prevent and fight this pandemic, countries have taken stringent restrictions such as working from home, quarantine for regions with a high number of cases and most importantly, lockdown. 
Lockdowns can restrict movement or activity in a community while allowing most organizations to operate normally, or they can restrict movement or activity such that only organizations that provide basic needs and services can operate normally [4]. By early April 2020, 3.9 billion people worldwide were under some form of lockdown-more than half the world's population [5], [6]. In the Philippines on March 16, 2020, President Rodrigo Duterte imposed an enhanced community quarantine (ECQ) in Luzon, which is effectively a total lockdown, restricting the movement of the population except for necessity, work, and health circumstances, in response to the growing pandemic of coronavirus disease 2019 (COVID-19) in the country [7]. The ECQ was supposed to last until April 12, but President of Philippines agreed to extend it until April 30 after the inter-agency task force on emerging infectious diseases (IATF-EID) recommended it [8].

During the lockdown period, a massive information dissemination campaign was carried out by the Department of Health about COVID-19 on different platforms such as in television, radio, newspaper, social and media. Its main objective is to educate and informed all individuals about COVID-19. Health education can improve an individual's knowledge of infectious diseases like COVID-19 and promote appropriate behaviors toward infectious disease prevention and control. It effectively slows the spread of contagious diseases like COVID-19 [9]. This research can help know the knowledge of infectious diseases like COVID19 in university students [10]. Therefore, it is crucial to understand current knowledge, attitude, and practices regarding the nature, transmission, and prevention of COVID-19 in the communities. This study aimed to evaluate student's knowledge, attitude and practice towards COVID-19.

\section{RESEARCH METHOD}

A descriptive research design was used to assess the knowledge, attitude and practice of the students of Nueva Ecija University of Science and Technology, San Isidro Campus, during the Luzon lockdown regarding the COVID-19 pandemic. It was initiated on March, simultaneous with the Enhanced Community Quarantine's implementation in the entire Luzon and completed on June 2020 after the Philippine government eases the restriction or puts the country under the General Community Quarantine. Purposive sampling was used to choose the respondents. The target population was all the students who have an active Messenger account and internet access. Only 179 participated and gave consent to take part in the study.

The questionnaire made by [10], [11] was adopted for the study. The questionnaire was modified for content, wording and cultural appropriateness following an extensive review of the literature published in English and expert opinions. The questionnaire was divided into five sections: The first part consisted of questions about their socio-demographic status (gender, parents' occupations, and monthly income); the second part consisted of questions about their knowledge of COVID-19, which included general knowledge, transmission, signs and symptoms, prevention, and the protocol and policy implemented in response to COVID-19; and the third part consisted of questions about their knowledge of COVID-19, which included general knowledge, transmission, sign and symptoms, prevention, and the protocol and policy implemented in response to COVID-19; The third section dealt with the source of information from which the respondents learned about COVID-19; the fourth part comprised statements regarding their attitude towards COVID-19; and the last part comprised statements about their practices done against COVID-19. The questionnaire was pre-tested among the said campus students before being included in the main report, but they were not included in the final review. The reliability coefficient, which is a measure of the questionnaire's internal accuracy, was calculated using Cronbach's Alpha [12]. Cronbach's Alpha coefficients obtain as a result of the analysis were 0.80 , which is acceptable [13]. A reliability score of at least 0.7 is considered good and approrpiate [14]. Due to the lockdown in the entire Luzon Island, which resulted in the suspension of classes in all levels, data gathering was done online using Google form as the questionnaire.

Permission was sought from the Director of the Campus. Before the respondent could answer the questionnaire, he or she had to give informed consent. The subjects' privacy and the confidentiality of the information were retained, and enough time was provided to ask questions.

All completed questionnaires were double-checked and validated. After that, the data from the Google form was entered into statistical packages for social sciences (SPSS). Until review, the author double-checked and cleaned all data files. The responses to the knowledge questions were coded with one (1) for correct answers and zero (0) for incorrect and "do not know" answers, with a maximum of 10 points for each category and 50 overall. The response was defined as correct if it was valid. "Do not know (DNN)", responses is equivalent to wrong answers [15]. According to Wang (1997) cited by [16], treating "DNN" as a wrong answer appears reasonable and justifiable in the study, although it is a conservative strategy. Dropping "DNN" responses from the data collection, on the other hand, decreases the sample size, introduces sample selection bias, and results in a significant loss of information. As a result, "DNN" was not removed from the analyses [16]. Further, knowledge for each category and the overall knowledge of students was calculated as a percentage, and knowledge level was classified as Very Poor $(<20 \%)$, Poor $(21-40 \%)$, 
Average (41-60\%), Good (61-80\%), and Very Good (81-100\%) based on 20\% cut-off point. For example, a respondent with scores between 50 and 41 on a total of 50 questions was classified as having very good knowledge, scores between 40 and 31 as good knowledge, scores between 30 and 21 as average knowledge, scores between 20 and 11 as bad knowledge, and scores between 10 and 0 as very poor knowledge. For the ten questions for each category, respondents with scores between 10 and 9 were classified as having very good knowledge, those with scores between 8 and 7 have good knowledge, those with scores between 6 and 5 have average knowledge, those with scores between 4 and 3 have poor knowledge, and those with scores between 2 and 0 have very poor knowledge. Attitudes towards COVID-19 were measured by 4 questions about the agreement on the importance of taking care and their confidence in fighting the virus. The assessment of respondents' practices was composed of 5 behaviors which include the different ways of preventing COVID-19. For the socio-demographic profile, frequency and percentage were computed, while One-way Analysis of Variance (ANOVA) was used to determine whether significant differences existed in their profile concerning their knowledge, attitude and practices towards COVID-19.

\section{RESULTS AND DISCUSSION}

\subsection{Socio-demographic profile of the respondents}

A total of 179 people were chosen to participate in the study, with 109 (60.90 percent) females and $70(39.10 \%)$ males. The majority of their father's occupations, $73(40.80 \%)$, were educated, and the majority of their mother's occupations, 80 (44.70\%), were skilled employees. The majority of them, 93 (52.0\%), had a monthly family income of P19,928 to P38,597 Table 1 . It can be noted that the number of unemployed (73 or $40.80 \%$ ) was due to the implementation of the enhanced community quarantine implemented in the Luzon since March 17, 2020. Because of the lockdown, closures in retail trade, malls, airports, canceled flights, and closures of non-food and non-health-related manufacturing services within the island were estimated to result in a maximum of one million people losing their jobs [17].

Table 1. Socio-demographic profile of the respondents

\begin{tabular}{|c|c|c|c|}
\hline \multicolumn{2}{|c|}{ Socio-demographic profile } & Frequency (f) & Percentage (\%) \\
\hline \multirow{2}{*}{ Gender } & Male & 70 & 39.10 \\
\hline & Female & 109 & 60.90 \\
\hline \multirow{4}{*}{ Occupation of father } & Professional & 39 & 21.80 \\
\hline & Skilled & 22 & 12.30 \\
\hline & Unskilled & 45 & 25.10 \\
\hline & Unemployed & 73 & 40.80 \\
\hline \multirow{4}{*}{ Occupation of mother } & Professional & 32 & 17.90 \\
\hline & Skilled & 80 & 44.70 \\
\hline & Unskilled & 44 & 24.60 \\
\hline & Unemployed & 23 & 12.80 \\
\hline \multirow{3}{*}{ Monthly gross family income } & P19,928 and below & 64 & 35.80 \\
\hline & P19,928-P38,597 & 93 & 52.00 \\
\hline & P38,597 and above & 22 & 12.00 \\
\hline
\end{tabular}

\subsection{Knowledge of the respondents about COVID-19}

According to the study's findings, 109 (60.89\%) respondents had good knowledge of the COVID-19 while $53(29.61 \%)$ had very good knowledge, $15(8.38 \%)$ had average knowledge, and only one $(0.56 \%)$ respondent had poor and very poor knowledge of the COVID-19 Table 2. The vast majority of respondents have excellent or excellent knowledge of COVID-19. One of the reason for these is According to [18], they respond socially to the pandemic as it develops, leading them to become more aware and knowledgeable about the said disease. It should be noted that the lockdown has provided pupils with more opportunities to watch television and surf the internet while at home, allowing them to expand their knowledge about COVID-19 [18]. Also, the study of [19] states that the respondents were not only aware; they are also staying up to date about the latest news about COVID-19. The study of [11] supported the result of the study wherein their respondents already have an average to good knowledge about COVID-19 before the entire Luzon was put in lockdown or Enhanced Community Quarantine. It only means that their knowledge about COVID-19 was enhanced in the time of lockdown sinces huge amount of information was disseminated.

In terms of their general knowledge about COVID-19, the result revealed that very good knowledge was found in $117(65.36 \%)$ respondents, good in 50 (27.93\%), average in $8(4.47 \%)$ and $2(1.12 \%)$ have poor and very poor knowledge. In terms of their knowledge about the transmission of COVID-19, data indicated that good knowledge was found in $104(58.10 \%)$ respondents, average in $35(19.55 \%)$, very good in $29(16.20 \%)$, poor in 9 $(5.03 \%)$ and $2(1.12 \%)$ had very poor knowledge. In terms of their knowledge about the sign and symptoms of 
COVID-19, findings indicated that average knowledge was found in 64 (35.75\%) respondents, good in 45 $(25.14 \%)$, very good knowledge in $32(25.14 \%)$, poor in $31(17.32 \%)$ and $7(3.91 \%)$ had very poor knowledge. In terms of their knowledge about the prevention of COVID-19, the result indicated that average knowledge was found in $70(39.11 \%)$ respondents, good in 69 (38.55\%), very good in $31(17.32 \%)$, poor in $7(3.91 \%)$ and 2 $(1.12 \%)$ had very poor knowledge. Last, in terms of their knowledge about the protocol implemented during the lockdown, the result of the study showed that many of them or $115(64.25 \%)$ have very good knowledge, good in $48(26.82 \%)$, average in $9(5.03 \%)$, poor in $4(2.23 \%)$ and $3(1.68 \%)$ have very poor knowledge Table 3.

Table 2. Knowledge scores of the respondents regarding COVID-19

\begin{tabular}{lccc}
\hline Level of knowledge & Criteria & Frequency (f) & Percentage (\%) \\
\hline Very good & $41-50$ & 53 & 29.61 \\
Good & $31-40$ & 109 & 60.89 \\
Average & $21-30$ & 15 & 8.38 \\
Poor & $11-20$ & 1 & 0.56 \\
Very poor & $0-10$ & 1 & 0.56 \\
\hline
\end{tabular}

Table 3. Knowledge scores of the respondents regarding COVID-19 in different category

\begin{tabular}{|c|c|c|c|c|c|c|c|c|c|c|c|}
\hline \multirow{2}{*}{ Level of knowledge } & \multirow{2}{*}{ Criteria } & \multicolumn{2}{|c|}{ General knowledge } & \multicolumn{2}{|c|}{ Transmission } & \multicolumn{2}{|c|}{ Sign and symptoms } & \multicolumn{2}{|c|}{ Prevention } & \multicolumn{2}{|c|}{ Protocol } \\
\hline & & $\mathrm{f}$ & $\%$ & $\mathrm{f}$ & $\%$ & $\mathrm{f}$ & $\%$ & $\mathrm{f}$ & $\%$ & $\mathrm{f}$ & $\%$ \\
\hline Very good & $10-9$ & 117 & 65.36 & 29 & 16.20 & 32 & 17.88 & 31 & 17.32 & 115 & 64.25 \\
\hline Good & $8-7$ & 50 & 27.93 & 104 & 58.10 & 45 & 25.14 & 69 & 38.55 & 48 & 26.82 \\
\hline Average & $6-5$ & 8 & 4.47 & 35 & 19.55 & 64 & 35.75 & 70 & 39.11 & 9 & 5.03 \\
\hline Poor & $4-3$ & 2 & 1.12 & 9 & 5.03 & 31 & 17.32 & 7 & 3.91 & 4 & 2.23 \\
\hline Very poor & $2-0$ & 2 & 1.12 & 2 & 1.12 & 7 & 3.91 & 2 & 1.12 & 3 & 1.68 \\
\hline
\end{tabular}

In terms of the respondents' mean score for general knowledge of COVID-19, the results showed that the majority of them got the correct response on all things except statement number 7, "Antibiotics are successful in treating COVID-19." The explanation for this may be that patients sometimes do not have a thorough understanding of antibiotics, mistaking "antibiotics" can cure COVID-19 [20], [21] discovered that people with lower educational status had less knowledge about antibiotics Table 4.

Table 4. Mean Scores of the respondents regarding their general knowledge about COVID-19

\begin{tabular}{|c|c|c|c|c|c|}
\hline \multirow[t]{2}{*}{ Item statements } & \multirow{2}{*}{$\begin{array}{c}\text { Mean } \\
\text { score/ } \\
\text { S.D. }\end{array}$} & \multicolumn{2}{|c|}{$\begin{array}{l}\text { Correct } \\
\text { answer }\end{array}$} & \multicolumn{2}{|c|}{$\begin{array}{l}\text { Wrong } \\
\text { answer }\end{array}$} \\
\hline & & $\mathrm{f}$ & $\%$ & f & $\%$ \\
\hline 1. Covid-19 is a new coronavirus that has spread throughout the world. & $0.97 \pm 0.17$ & 174 & 97.21 & 5 & 2.79 \\
\hline 2. There are indications that COVID-19 curve is flattening in the Philippines. & $0.84 \pm 0.36$ & 151 & 84.36 & 28 & 15.64 \\
\hline $\begin{array}{l}\text { 3. You must isolate for } 14 \text { days if you have been diagnosed with COVID-19 or have } \\
\text { had some contact with someone who has been diagnosed with COVID-19. }\end{array}$ & $0.95 \pm 0.22$ & 170 & 94.97 & 9 & 5.03 \\
\hline 4. The clinical recovery for mild cases is approximately $2-6$ weeks. & $0.83 \pm 0.37$ & 149 & 83.24 & 30 & 16.76 \\
\hline 5. Covid-19 is considered as pandemic. & $0.96 \pm 0.19$ & 172 & 96.09 & 7 & 3.91 \\
\hline $\begin{array}{l}\text { 6. All travelers or overseas Filipino workers (OFW) that are heading home needed to be } \\
\text { quarantined first before they go to their town }\end{array}$ & $0.97 \pm 0.18$ & 173 & 96.65 & 6 & 3.35 \\
\hline 7. Antibiotics are effective against COVID-19. & $0.35 \pm 0.48$ & 63 & 35.20 & 116 & 64.80 \\
\hline 8. Everyone is at risk of getting COVID-19. & $0.93 \pm 0.26$ & 166 & 92.73 & 13 & 7.26 \\
\hline 9. Enhance Community Quarantine are implemented to stop COVID-19. & $0.96 \pm 0.21$ & 171 & 95.53 & 8 & 4.47 \\
\hline 10. As of now USA has the most number of positive cases of COVID-19. & $0.78 \pm 0.42$ & 139 & 77.65 & 40 & 22.34 \\
\hline
\end{tabular}

In terms of the respondents' mean score on their knowledge of COVID-19 transmission, the results showed that most respondents correctly answered all of the questions. Only item statement number 7 "COVID- 19 can't be transmitted in areas hot and humid climates" got the least of the correct answer. The explanation for this may be that experiments showing that germicidal ultraviolet radiation (UV-C) destroys the virus in hospitals and laboratories have been misinterpreted as proof that sunlight (a combination of UVA and UV-B) can effectively neutralize the virus in outdoor public spaces [22]. The respondents' knowledge about the effects of temperature on the virus makes them mistakenly perceive that the COVID-19 virus cannot be transmitted in hot and humid places Table 5 .

In terms of the mean score of the respondents regarding their knowledge about the sign and symptoms of COVID-19, the result showed that the majority of them got the correct answer on all items except on item statement number 3, "Fatigue is not a symptom of COVID-19" and item statement number 7 "Bluish lips or face is a sign of COVID-19" Table 6. Fever, cough, and dyspnea were the typical clinical manifestation of COVID-19. Good knowledge of the signs and symptoms of a contagious disease like COVID-19 is essential to be familiar with the disease [23]. 
Table 5. Mean scores of the respondents regarding their knowledge about the transmission of COVID-19

\begin{tabular}{|c|c|c|c|c|c|}
\hline \multirow{2}{*}{ Item Statements } & \multirow{2}{*}{$\begin{array}{c}\text { Mean Score/ } \\
\text { S.D. }\end{array}$} & \multicolumn{2}{|c|}{ Correct answer } & \multicolumn{2}{|c|}{ Wrong answer } \\
\hline & & $\mathrm{f}$ & $\%$ & $\mathrm{f}$ & $\%$ \\
\hline 1. Close contact with infected people can transmit the virus. & $0.93 \pm 0.26$ & 166 & 92.74 & 13 & 7.26 \\
\hline 2. Close contact with infected people through droplets of their coughs or sneezes. & $0.93 \pm 0.26$ & 166 & 92.74 & 13 & 7.26 \\
\hline 3. Touching objects or surfaces contaminated by COVID-19 positive patient. & $0.88 \pm 0.33$ & 157 & 87.71 & 22 & 12.29 \\
\hline 4. The more space between you and others, the harder it is for the virus to spread. & $0.91 \pm 0.29$ & 163 & 91.06 & 16 & 8.94 \\
\hline 5. Travelers who have been recently overseas are more at risk of getting infected. & $0.87 \pm 0.34$ & 155 & 86.59 & 24 & 13.41 \\
\hline 6. Close contact like hugging or shaking hands can't transmit the virus. & $0.34 \pm 0.48$ & 118 & 65.92 & 61 & 34.08 \\
\hline 7. COVID- 19 can't be transmitted in areas with hot and humid climates. & $0.60 \pm 0.49$ & 108 & 60.34 & 71 & 39.66 \\
\hline $\begin{array}{l}\text { 8. Touching contaminated objects and surfaces and then touching your face can } \\
\text { transmit the virus. }\end{array}$ & $0.91 \pm 0.29$ & 163 & 91.06 & 16 & 8.94 \\
\hline 9. Taking a hot bath can prevent the transmission of corona virus & $0.16 \pm 0.36$ & 151 & 84.36 & 28 & 15.64 \\
\hline 10. There's an evidences that pets have been infected or have spread COVID-19. & $0.64 \pm 0.48$ & 114 & 63.69 & 65 & 36.31 \\
\hline
\end{tabular}

Table 6 . Mean scores of the respondents regarding their knowledge about the sign and symptoms of COVID-9

\begin{tabular}{lccccc}
\multicolumn{1}{c}{ Item statements } & Mean score/ & \multicolumn{2}{c}{ Correct answer } & \multicolumn{2}{c}{ Wrong answer } \\
& S.D. & f & $\%$ & f & $\%$ \\
\hline 1. Fever is a sign of COVID-19. & $0.93 \pm 0.25$ & 167 & 93.30 & 12 & 6.70 \\
2. Cough is not a symptom of COVID-19. & $0.62 \pm 0.49$ & 111 & 62.01 & 68 & 37.99 \\
3. Fatigue is not a symptom of COVID-19. & $0.40 \pm 0.49$ & 71 & 39.66 & 108 & 60.34 \\
4. Lack of Appetite is one of the symptoms of COVID-19. & $0.58 \pm 0.49$ & 104 & 58.10 & 75 & 41.90 \\
5. Shortness of breath is not a symptom of COVID-19. & $0.60 \pm 0.49$ & 107 & 59.78 & 72 & 40.22 \\
6. Chills is one of the symptom of COVID-19. & $0.56 \pm 0.50$ & 100 & 55.87 & 79 & 44.13 \\
7. Bluish lips or face is a symptoms of COVID-19 & $0.40 \pm 0.49$ & 71 & 39.66 & 108 & 60.34 \\
8. Constant pain or pressure in your chest is a sign of COVID-19. & $0.79 \pm 0.41$ & 142 & 79.33 & 37 & 20.67 \\
9. Pneumonia like symptoms can also be a COVID-19. & $0.83 \pm 0.37$ & 149 & 83.24 & 30 & 16.76 \\
10. Sore throat is not a indication of COVID-19. & $0.57 \pm 0.50$ & 102 & 56.98 & 77 & 43.02 \\
\hline
\end{tabular}

In terms of the respondents' mean score regarding their knowledge about the prevention of COVID19 , the result revealed that the majority of them got the correct answer on all items except on item statement number 6 "You can protect yourself against the virus by simply gargling bleach," and item statement number 9 "Inhaling steam from warm water can eliminate the virus from your system" [24] say that awareness about the disease, especially in preventing it, is one of the main factors that determine the success of a control program in an infectious disease like COVID-19 Table 7. According to the report by [25], people are engaging in extremely dangerous behaviors-including gargling with bleach - to prevent COVID-19. Another practice found by [26] said that steam inhalation cab used to treat and to avoid COVID-19. Both of these practices do nothing to treat and prevent COVID-19 [25], [26]. The reason for this misconception is the fact that bleach does kill viruses like COVID-19 but only for disinfection [27]. In steam inhalation, they theorized that the effects of both heat and humidity of warm, moist air could kill the virus since it is already used as a traditional home remedy and treatment for respiratory conditions like common colds, and flu [28], [29].

In terms of the respondents' mean score regarding their knowledge about the protocol implemented in response to COVID-19, the result showed that the majority of them got the correct answer on all items. Only item statement number 8, "All laboratories in the Philippines can conduct a confirmatory test about COVID-19," got the least of the correct answer Table 8. Some steps need to be accomplished before the said laboratory becomes operational, meaning that not all laboratories in the Philippines can conduct a confirmatory test for COVID-19 [30].

Table 7. Mean scores of the respondents regarding their knowledge about the prevention of COVID-19

\begin{tabular}{|c|c|c|c|c|c|}
\hline \multirow{2}{*}{ Item statements } & \multirow{2}{*}{$\begin{array}{c}\text { Mean score/ } \\
\text { S.D. }\end{array}$} & \multicolumn{2}{|c|}{ Correct answer } & \multicolumn{2}{|c|}{ Wrong answer } \\
\hline & & $\mathrm{f}$ & $\%$ & $\mathrm{f}$ & $\%$ \\
\hline 1. Avoiding touching your face can minimize the chance of catching the virus. & $0.98 \pm 0.15$ & 175 & 97.77 & 4 & 2.23 \\
\hline 2. Always wash your hands with soap thoroughly. & $0.97 \pm 0.17$ & 174 & 97.21 & 5 & 2.79 \\
\hline 3. Wearing face masks can reduce the chance of spreading the virus. & $0.96 \pm 0.19$ & 172 & 96.09 & 7 & 3.91 \\
\hline 4. Antibiotic are effective preventing COVID- 19 . & $0.23 \pm 0.42$ & 138 & 77.09 & 41 & 22.91 \\
\hline 5. Prevent attending gatherings to protect yourself against the virus. & $0.91 \pm 0.29$ & 163 & 91.06 & 16 & 8.94 \\
\hline 6. You can protect yourself against the virus by simply gargling bleach. & $0.42 \pm 0.49$ & 75 & 41.90 & 104 & 58.10 \\
\hline 7. Drinking alcohol reduces the risk of being infected by the virus. & $0.60 \pm 0.49$ & 107 & 59.78 & 72 & 40.22 \\
\hline 8. Use $50 \%$ ethyl alcohol to eliminate the virus immediately. & $0.48 \pm 0.50$ & 86 & 48.04 & 93 & 51.96 \\
\hline 9. Inhaling steam from warm water can eliminate the virus from your system. & $0.28 \pm 0.45$ & 51 & 28.49 & 128 & 71.51 \\
\hline 10. To avoid the virus, keep a safe distance for at least one meter from other people. & $0.92 \pm 0.27$ & 165 & 92.18 & 14 & 7.82 \\
\hline
\end{tabular}

Int. J. Public Health Sci., Vol. 10, No. 3, September 2021: 670-678 
Table 8. Mean scores of the respondents regarding their knowledge about the protocol implemented in response to the COVID-19

\begin{tabular}{|c|c|c|c|c|c|}
\hline \multirow{2}{*}{ Item statements } & \multirow{2}{*}{$\begin{array}{c}\text { Mean score/ } \\
\text { S.D. }\end{array}$} & \multicolumn{2}{|c|}{ Correct answer } & \multicolumn{2}{|c|}{ Wrong answer } \\
\hline & & $\mathrm{f}$ & $\%$ & $\mathrm{f}$ & $\%$ \\
\hline 1. Confirmed positive individual should be known by public. & $0.84 \pm 0.37$ & 150 & 73.70 & 29 & 23.50 \\
\hline 2. Government mandate young, senior and high health risk individuals to stay home. & $0.94 \pm 0.24$ & 168 & 73.70 & 11 & 26.30 \\
\hline 3. Government imposes liquor ban to certain areas during the fight against COVID. & $0.91 \pm 0.29$ & 162 & 80.20 & 17 & 19.80 \\
\hline 4. Public transportation systems are suspended amid COVID-19. & $0.95 \pm 0.22$ & 170 & 77.30 & 9 & 22.70 \\
\hline 5. Hospitals must cremate COVID-19 victims in 12 hours. & $0.82 \pm 0.39$ & 146 & 74.00 & 33 & 26.00 \\
\hline 6. Suspected patients and frontliners are prioritized in testing for COVID-19. & $0.88 \pm 0.32$ & 158 & 33.50 & 21 & 66.50 \\
\hline 7. A 14-day facility quarantine is required for all returning OFWs. & $0.96 \pm 0.21$ & 171 & 33.70 & 8 & 66.30 \\
\hline 8. All laboratories in the Philippines can conduct confirmatory test for COVID-19. & $0.68 \pm 0.47$ & 122 & 27.70 & 57 & 72.30 \\
\hline 9. Inhaling steam from warm water can eliminate the virus from your system. & $0.77 \pm 0.42$ & 157 & 29.00 & 42 & 71.00 \\
\hline 10. All mass gatherings are prohibited amid COVID-19 pandemic. & $0.88 \pm 0.33$ & 157 & 44.90 & 22 & 55.10 \\
\hline
\end{tabular}

\subsection{Source of information of the respondents to their knowledge about COVID-19.}

Table 9 shows the source of knowledge of the respondents. Based on the result, their main source of information is from the news they watch on television. The study of [19] supported the result, wherein their respondents responded that their information about the COVID-19 pandemic was obtained through traditional media like television. It is followed by the articles they read on different social media platforms like Facebook. The same result was obtained by [31] that the internet and TV were the main sources of information of their participants about COVID-19. Also, during the $2009 \mathrm{H}_{1} \mathrm{~N}_{1}$ (a contagious disease just like COVID-19) outbreak, the internet was cited as the most frequently used source of information [32]. Furthermore, most of the available information was in English, making it more understandable to the respondents [33]. However, [34] stated that information from the internet through different social media platforms was limited because not all people do not own a device that can access social media and only had limited internet connectivity.

Table 9. Source of knowledge of the respondents about COVID-19

\begin{tabular}{|c|c|c|c|c|c|}
\hline Source of knowledge & Mean & Rank & Source of knowledge & Mean & Rank \\
\hline 1. Media coverage & 6.46 & $3^{\text {rd }}$ & 6. From television & 7.24 & $1^{\text {st }}$ \\
\hline 2. From radio & 5.79 & $9^{\text {th }}$ & 7. From magazine and newspaper & 5.99 & $8^{\text {th }}$ \\
\hline 3. Campaign from public health authorities & 6.22 & $6^{\text {th }}$ & 8. Seminar awareness from your school & 6.23 & $5^{\text {th }}$ \\
\hline 4. From your friends & 5.37 & $10^{\text {th }}$ & 9. From social media & 6.79 & $2^{\text {nd }}$ \\
\hline 5. From your relatives & 6.16 & $7^{\text {th }}$ & 10. Awareness campaign of your community & 6.39 & $4^{\text {th }}$ \\
\hline
\end{tabular}

\subsection{Attitudes and practices of the respondents towards COVID-19}

Table 10 shows the attitude of the respondents towards COVID-19. All statements obtained a weighted mean higher than 4.30 with a verbal interpretation "Strongly agree." It denotes that most of them had a positive attitude towards COVID-19. The result was supported by the study of [35], wherein their participants showed a positive and optimistic attitude toward COVID-19. According to their participants, the virus can be successfully controlled and their government will control the pandemic. However, the study conducted by [36] about the attitude of the school children of Nigeria towards the Ebola virus infection, which is also an infectious disease, was negative. Table 11 shows the practices of the respondents towards COVID-19. Almost all of them responded "Yes" on all the statements, which refer to some ways to prevent COVID-19. One of the statements they have mostly done is wearing masks whenever they go outside since the preventive significance of using masks in reducing respiratory viral infection was proven [37].

Table 10. Attitude of the respondents towards COVID-19

\begin{tabular}{lcc}
\hline \multicolumn{1}{c}{ Item statements } & Weighted mean & Verbal interpretation \\
\hline 1. We can fight and defeat COVID-19 & 4.60 & Strongly agree \\
2. I will do everything I can to protect myself and my family. & 4.39 & Strongly agree \\
3. Following the directions of your local health authority can protect us from COVID- & 4.32 & Strongly agree \\
4. It is important that people take more care of each other now during the pandemic. & 4.35 & Strongly agree \\
\hline
\end{tabular}

Table 11. Practices of the respondents towards COVID-19

\begin{tabular}{lcc}
\hline \multicolumn{1}{c}{ Item statements } & Yes (\%) & No (\%) \\
\hline 1. I am practicing social distancing. & $170(94.97)$ & $9(5.03)$ \\
2. I stay at home to avoid catching the virus. & $173(96.65)$ & $6(3.35)$ \\
3. I wear masks whenever I go outside my hor & $175(97.77)$ & $4(2.23)$ \\
4. I take vitamins to boost my immune systen & $173(96.65)$ & $6(3.35)$ \\
5. I sanitize my hands using alcohol. & $175(97.77)$ & $4(2.23)$ \\
\hline
\end{tabular}




\subsection{Difference between their profile and their knowledge, attitude and practices about COVID-19}

Table 12 shows the difference between the respondents' profile and their knowledge scores, attitude and practices regarding COVID-19. Regarding the difference between their profile and their knowledge about COVID-19, only sex and family income have a significant difference. The result was supported by the studies of [38], [39]. Both of them found that female has higher health awareness and more knowledgeable in infectious disease than male. One explanation for this is that women have more access to knowledge, public relations, and interest, and they can spend more time watching television shows [40]. Also, [41] state that men were significantly less likely to take preventive and protective measures than women. Besides, [42] stated that men are often unwilling or unable to engage with health-related knowledge during stressful life events and daily lives. Since the mean score of the respondent who belongs above the poverty level was lower compared to those below the poverty level contradicts the result of [43]. According to them, those living below the poverty level have limited ability to prevent an infection like COVID-19, which may be due to feeling less able to change one's social circumstance or lack of public health communications. Last, the difference between their profile and their attitude and practices is insignificant.

Table 12. Difference between the profile of the respondents and their knowledge scores, attitude and practices regarding COVID-19

\begin{tabular}{|c|c|c|c|c|c|c|c|}
\hline \multicolumn{2}{|c|}{ Variables } & \multirow{2}{*}{$\begin{array}{c}\text { Knowledge } \\
\text { scores } \\
\text { mean } \pm \text { S.D. }\end{array}$} & \multirow{3}{*}{$\begin{array}{l}\text { p-value } \\
0.0069 *\end{array}$} & \multirow{3}{*}{$\begin{array}{c}\begin{array}{c}\text { Attitude } \\
\text { mean } \pm \\
\text { S.D. }\end{array} \\
4.41 \pm 0.58 \\
4.42 \pm 0.61\end{array}$} & \multirow{3}{*}{$\begin{array}{c}\begin{array}{c}\mathrm{p}- \\
\text { value }\end{array} \\
0.9612\end{array}$} & \multirow{3}{*}{$\begin{array}{c}\text { Practice } \\
\text { mean } \pm \\
\text { S.D } \\
1.05 \pm 0.16 \\
1.02 \pm 0.08\end{array}$} & \multirow{3}{*}{$\begin{array}{c}\begin{array}{c}\mathrm{p}- \\
\text { value }\end{array} \\
0.1975\end{array}$} \\
\hline & Male & & & & & & \\
\hline Gender & Female & $38.28 \pm 4.91$ & & & & & \\
\hline \multirow{4}{*}{ Occupation of father } & Professional & $37.54 \pm 5.83$ & \multirow{4}{*}{0.9552} & $4.41 \pm 0.58$ & \multirow{4}{*}{0.8845} & $1.04 \pm 0.10$ & \multirow{4}{*}{0.3126} \\
\hline & Skilled & $36.77 \pm 5.13$ & & $4.42 \pm 0.61$ & & $1.00 \pm 0.00$ & \\
\hline & Unskilled & $37.18 \pm 3.38$ & & $4.38 \pm 0.61$ & & $1.05 \pm 0.18$ & \\
\hline & Unemployed & $37.49 \pm 6.55$ & & $4.41 \pm 0.49$ & & $1.02 \pm 0.09$ & \\
\hline \multirow{4}{*}{ Occupation of mother } & Professional & $36.59 \pm 5.67$ & \multirow{4}{*}{0.7316} & $4.38 \pm 0.68$ & \multirow{4}{*}{0.4494} & $1.03 \pm 0.09$ & \multirow{4}{*}{0.5969} \\
\hline & Skilled & $37.21 \pm 6.13$ & & $4.46 \pm 0.57$ & & $1.04 \pm 0.15$ & \\
\hline & Unskilled & $38.11 \pm 6.23$ & & $4.51 \pm 0.64$ & & $1.01 \pm 0.05$ & \\
\hline & Unemployed & $37.30 \pm 4.93$ & & $4.33 \pm 0.62$ & & $1.05 \pm 0.14$ & \\
\hline \multirow{3}{*}{$\begin{array}{l}\text { Monthly gross family } \\
\text { income }\end{array}$} & $\begin{array}{l}\text { P19,928 and } \\
\text { below }\end{array}$ & $37.00 \pm 5.16$ & \multirow{3}{*}{$0.0439 *$} & $4.47 \pm 0.50$ & \multirow{3}{*}{0.4714} & $1.03 \pm 0.14$ & \multirow{3}{*}{0.9640} \\
\hline & P19,928-P38,597 & $38.17 \pm 5.96$ & & $4.46 \pm 0.63$ & & $1.03 \pm 0.11$ & \\
\hline & $\begin{array}{l}\mathrm{P} 38,597 \text { and } \\
\text { above }\end{array}$ & $34.77 \pm 7.08$ & & $4.45 \pm 0.56$ & & $1.03 \pm 0.09$ & \\
\hline
\end{tabular}

Legend: *significant at $\mathrm{p} \leq 0.05$

\section{CONCLUSION}

It was concluded that the majority of the respondents had good to very good knowledge of COVID19 and their source of knowledge was mainly from television and the internet. They also had a very positive attitude towards COVID-19 and they practice the following: practicing social distancing, staying at home, wear a mask when going outside their home, sanitize their hands and take vitamins to boost their immune system. There is a significant difference between the respondents' gender and family income to their knowledge about COVID-19. The pandemic brought by COVID-19 was far from over since all the candidate vaccines are still in their clinical trials. Because of this, the only way to control the onslaught of the disease is to prevent and control it. With this, one must ensure that he/she has enough knowledge, a positive attitude and doing the correct practices against COVID-19 is very important. To ensure this, it is suggested that an intensified campaign against this deadly and contagious virus should be done to reach those individuals who have limited access to television and the internet and help them to have a positive attitude and practice all the routine that can help to prevent and stop COVID-19.

\section{REFERENCES}

[1] Zu Z. Y. et al., "Coronavirus disease 2019 (COVID-19): a perspective from China," Radiology, vol. 296, no. 2, pp. 15-25, 2020, doi: 10.1148/radiol.2020200490.

[2] Wang D. et al., "Clinical characteristics of 138 hospitalized patients with 2019 novel coronavirus-infected pneumonia in Wuhan, China," Jama, vol. 323, no. 11, pp. 1061-1069, Feb. 2020, doi: 10.1001/jama.2020.1585.

[3] O'Kane C., "Pangolins are possible coronavirus hosts, Chinese scientists say. CBS News - Breaking news, 24/7 live streaming news and top stories. 2020. [Online]. Available: https://www.cbsnews.com/news/pangolincoronavirus-scale-anteater-possible-host-of-virus-chinese-scientists-say/ 
[4] D. Kevin, D. J. Paolo, "COVID-19 Crisis Management and Prevention Plan," COVID-19 Plan, pp. 1-25, 2020, doi: 10.13140/RG.2.2.26883.66089.

[5] WHO, "Rolling Updates on Coronavirus Disease (COVID-19)," 2020. [Online]. Availabe: https://www.who.int/emergencies/diseases/novel-coronavirus-2019/events-as-they-happen. July 31, 2020

[6] L. Jaimy, "Market Watch, 2020. COVID-19 case tally: 124,578 cases, 4,584 deaths," 2020. [Online] Available: https://www.marketwatch.com/story/covid-19-case-tally-120944-cases-4365-deaths-2020-03-11. March 11, 2020

[7] M. Arianne, "Luzon under enhanced community quarantine as COVID-19 cases rises," 2020. [Online]. Available: https://news.abs-cbn.com/news/03/16/20/duterte-places-luzon-under-enhanced-community-quarantine-to-fightcovid-19. March 16, 2020.

[8] C. Andreo, "Duterte likely to extend Philippines coronavirus lockdown," The Jakarta Post. [2020]. Available: https://www.thejakartapost.com/seasia/2020/04/06/duterte-likely-to-extend-philippines-coronavirus-lockdown1586192040.html.

[9] Jedrzejewska B., Kalinowski P., and Stachowicz A, "Knowledge of healthy behaviours among teenagers attending selected schools of the Lublin region," Annales Academiae Medicae Stetinensis, vol. 51, pp. 65-69, 2005.

[10] S. Tayyaba and Q. M. Imran, "Sagacity about SARS among University Students," Open Access Journal of Oncology and Medicine, vol. 2, no. 4, pp. 199-201, 2019, doi: 10.32474/OAJOM.2019.02.000145.

[11] Santiago J. M. and Cajucom R. L, "Knowledge about COVID-19 among university students before the implementation of the enhanced community quarantine in Philippines," International Journal of Public Health, vol. 9, no. 4, pp. 321-328, Dec. 2020.

[12] Cronbach LJ, "Coefficient alpha and the internal structure of tests," Psychometrika, vol. 16, pp. 297-334, 1951, doi: 10.1007/BF02310555.

[13] Van Griethuijsen et al., "Global patterns in students' views of science and interest in science," Research in science education 45, no. 4, pp. 581-603, 2015.

[14] Madan C. R. and Kensinger E. A., "Test-retest reliability of brain morphology estimates," Brain Informatics, vol. 4, no. 2, 107-121, 2017.

[15] Luskin RC and Bullock JG, “'Don't Know' means 'Don't Know': DK responses and the public's level of political knowledge,” Journal Politics, vol. 73, no. 2, pp. 547-557, 2011.

[16] Dhimal M. et al., "Knowledge, attitude and practice regarding dengue fever among the healthy population of highland and lowland communities in central Nepal," PLoS One, vol. 9, no. 7, 2014.

[17] S. M. Jean, "Philippines: Coronavirus COVID-19 employment impact 2020," Statista, 2020. [Online]. Available: https://www.statista.com/statistics/1106978/philippines-employment-impact-novel-coronavirus-covid19/

[18] Carducci A. et al., "Environment and health: Risk perception and its determinants among Italian university students," Science of The Total Environment, vol. 691, pp. 1162-1172, 2019.

[19] Lau L., "Knowledge, attitudes and practices of COVID-19 among income-poor households in the Philippines: a cross-sectional study," Journal of Global Health, vol. 10, no. 1, pp. 1-11, 2020, doi: 10.7189/jogh.10.011007

[20] Pagnini F. et al., "Knowledge, concerns, and behaviors of individuals during the first week of the coronavirus disease 2019 pandemic in Italy," JAMA Network Open, vol. 3, no. 7, pp. e2015821-e2015821, 2020.

[21] Vallin M. et al., "Knowledge and attitudes towards antibiotic use and resistance-a latent class analysis of a Swedish population-based sample," PloS One, vol. 11, no. 4, 2016.

[22] Seyer A. and Sanlidag T., "Solar ultraviolet radiation sensitivity of SARS-CoV-2," The Lancet Microbe, vol. 1, no. 1, pp. e8-e9, 2020, doi: 10.1016/S2666-5247(20)30013-6.

[23] Huang C. et al., "Clinical features of patients infected with 2019 novel coronavirus in Wuhan, China," The Lancet, vol. 395, no. 10223, pp. 497-506, 2020.

[24] Wijerathna T., Gunathilaka N., Gunawardana K, and W. Rodrigo, "Potential challenges of controlling leishmaniasis in Sri Lanka at a disease outbreak," BioMed Research International, vol. 2017, pp. 1-9, 2017, doi: $10.1155 / 2017 / 6931497$

[25] E. Erika, "CDC report on COVID-19 cleaning practices finds some gargling with bleach. That's very dangerous," 2020. [Online]. Available: https://www.nbcnews.com/health/health-news/cdc-report-covid-19-cleaning-practicesfinds-some-gargling-bleach-n1225826

[26] Uy T. M. Z., Miranda M. C. B., AroS. J. V., and Uy M. E. V, "Should steam inhalation be used in the treatment and prevention of COVID-19?," Asia Pasific Center Evidence Based Healthcare, July 11, 2020.

[27] U.S., "Centers for Disease Control and Prevention. Coronavirus disease 2019 (COVID-19): Cleaning and disinfection for households," 2020 [Online]. Available: https://www.cdc.gov/coronavirus/2019-ncov/preventgetting-sick/cleaning-disinfection.html

[28] Vathanophas V., Pattamakajonpong P., Assanasen P., and Suwanwech T., "The effect of steam inhalation on nasal obstruction in patients with allergic rhinitis," Asian Pac J Allergy Immunol., 2019, doi: 10.12932/AP-090818-0393.

[29] Fokkens WJ. et al., "European Position Paper on Rhinosinusitis and Nasal Polyps 2020," Rhinology, vol. 58, no. Suppl S29, pp. 1-464, 2020, doi: 10.4193/Rhin20.600

[30] Research Institute for Tropical Medicine, "Assessment of testing labs crucial for COVID-19 results accuracy," 2020. [Online]. Available: https://ritm.gov.ph/assessment-of-testing-labs-crucial-for-covid-19-results-accuracy/

[31] Elnadi H., Odetokun I. A., Bolarinwa O., Ahmed Z., Okechukwu O., and Al-Mustapha A. I., "Knowledge, attitude, and perceptions towards the 2019 Coronavirus Pandemic: A bi-national survey in Africa," PLoS ONE, pp. 1-13, 2020, doi: https://doi.org/10.1371/journal.pone.0236918. 
[32] Jones J. and Salathe M., "Early assessment of anxiety and behavioural response to novel swine-origin influenza A (H1N1)," PLoS ONE, vol. 4, no. 12, pp. 1-8, Dec. 2009, doi: 10.1371/journal.pone.0008032.

[33] Santiago Jomell M. and David Eden S., "The Use of Two Media of Instruction in Biology: A Quasi-Experimental Study," International Journal of Advanced Engineering, Management and Science, vol. 5, no. 2, pp. 111-115, 2019.

[34] Pastor C. K. L., "Sentiment Analysis on Synchronous Online Delivery of Instruction due to Extreme Community Quarantine in the Philippines caused by Covid-19 Pandemic," Asian Journal of Multidisciplinary Studies, vol. 3, no. 1, pp. 1-6. 2020.

[35] Mohammed K et al., "Knowledge, Attitude and Practice Toward COVID-19 Among the Public in the Kingdom of Saudi Arabia: A Cross-Sectional Study," Frontiers in Public Health, vol. 8, pp. 1-10, 2020.

[36] Ilesanmi O., and Alele F. O., "Knowledge, attitude and perception of Ebola virus disease among secondary school students in Ondo State, Nigeria, October, 2014," PLoS Currents, vol. 8, pp. 1-11, 2016.

[37] Radonovich L. J., et al., "N95 respirators vs medical masks for preventing influenza among health care personnel: a randomized clinical trial," JAMA, vol. 322, no. 9, pp. 824-833, 2019.

[38] Taylor M., "Gender differences in health literacy about tuberculosis (TB) amongst South African high school students," American Journal of Tropical Medicine and Hygiene, vol. 83, no. 5, pp. 201-201, 2020.

[39] Guo B. et al., "Investigation on the status of health knowledge level of medical students in a medical university," Medicine and Society, vol. 25, no. 7, pp. 10-12, 2012.

[40] Ebrahimi M. M., Topchiyan A., Farsad N. E., and Noor M. M., "Knowledge and attitude about women's heart disease risk factorsobesity, CVD and its relationship Obesity index and biochemical factors," University of Medical Sciences magazine of Tabriz, vol. 33, no. 2, pp. 7-12. 2011.

[41] Moran K. R. and Del Valle S. Y., "A meta-analysis of the association between gender and protective behaviors in response to respiratory epidemics and pandemics," PloS ONE, vol. 11, no. 10, pp. 1-25, 2016.

[42] Wellstead P., "Information behaviour of Australian men experiencing stressful life events: the role of social networks and confidants," Information Research, vol. 16, no. 2, pp. 16-2 2011.

[43] Wolf M. S. et al., "Awareness, attitudes, and actions related to COVID-19 among adults with chronic conditions at the onset of the US outbreak: a cross-sectional survey," Annals of Internal Medicine, vol. 173, no. 2, pp. 100-109, 2020, doi: 10.7326/M20-1239. 